\title{
Remembrance Day Practices in Schools: Meaning-making in Social Memory during the First World War Centenary
}

\author{
Annie Haight ${ }^{\mathrm{a} *}$, Susannah Wright ${ }^{\mathrm{b}}$, David Aldridge ${ }^{\mathrm{c}}$ and Patrick Alexander ${ }^{\mathrm{d}}$ \\ ${ }^{a}$ School of Education, Oxford Brookes University, Oxford, UK Twitter: @Deedlenay; ${ }^{b}$ School \\ of Education, Oxford Brookes University, Oxford,UK, Twitter: @susannahlwright; \\ ${ }^{c}$ Department of Education, Brunel University, London,UK, Twitter: @zudensachen; ${ }^{d}$ School \\ of Education, Oxford Brookes University, Oxford,UK, Twitter: @PatGAlexander
}

School of Education, Oxford Brookes University, Harcourt Hill Campus, Oxford, UK, OX2 9AT

*ahaight@brookes.ac.uk

\section{Author Biographies}

Annie Haight is a senior lecturer in the School of Education at Oxford Brookes University. Her research interests centre on the sociology and philosophy of education, and the ways in which debates in the sphere of education reflect and illuminate aspects of wider culture and society.

Susannah Wright is a Senior Lecturer in Education Studies in the School of Education, Oxford Brookes University, Her key research interests and publications focus on moral education and citizenship, and local studies of education and welfare in late nineteenth and early twentieth century Britain. In addition to the research on remembrance in schools represented in this article, other current research projects focus on young people, commemoration, and engagement with internationalism and pacifism from the 1920 s to the 1960s. 
David Aldridge is Reader and Director of Research in the Department of Education at Brunel University London. His research interests include philosophy of education, religious and moral education, and the relation between literature and education.

Patrick Alexander is Research Lead and Director of the Centre of Educational Consultancy and Development in the School of Education, Oxford Brookes University. Patrick's research interests lie at the intersection of education, anthropology, and youth studies, focusing on the sociology of schooling and youth transitions. 


\section{Remembrance Day Practices in Schools: Meaning-making in Social Memory during the First World War Centenary}

\section{Abstract}

Each November, commemoration of the First World War armistice (and subsequent military events and conflicts) is almost ubiquitous in UK schools and has been given increased importance during the centenary years of the First World War. Yet as seemingly isolated occasions outside the regular curriculum, school practices of remembrance, and the understandings and perceptions surrounding them, have been subject to surprisingly little scrutiny. The Remembrance in Schools project (2013-19) investigates armistice commemoration in primary and secondary schools in three counties in southern England. This paper considers the theorisation of public commemorative rituals and relates this to teachers' reports of school-based events. It analyses teachers' accounts and perceptions, from survey and interview data, of the ways in which the First World War and subsequent conflicts are remembered, presented and discussed through school commemoration events. We conclude that such events mirror the 'social technologies' of public remembrance rituals. However, behind almost ubiquitous practices (the two-minute silence) and symbols (the poppy), these accounts reveal nuanced variations in teachers' views of the knowledge and values children gain from armistice commemoration in schools. These variations are inflected by individual schools' histories, community contexts, and pupil demographics, as well as teachers' own histories, values and ideals.

Keywords: First World War; remembrance; teachers' perceptions; social memory

\section{Introduction}

If we accept R.S. Peters's (1966) proposition that education is a conversation between the generations, then arguably all education is an act of remembrance: on the part of older 
generations, recalling and communicating memories; on the part of the younger generation, laying memories down and accessing the memories of their elders. Half a century after Peters, Tim Ingold (2017) has argued that the 'genealogical model' of mass education places memory at the heart of learning, with one generation imbuing the next with remembered knowledge that will in turn be passed on in the long process of reproducing culture. At least some of the memories in the educational project will be collective and culturally-based, described by Jay Winter as 'historical remembrance' and by Paul Connerton as 'social memory' (Winter 2008, 6; Connerton 1989, 1). The growth of 'memory studies' as a branch of the humanities over the past four decades has entailed an increased theorisation of memory, commemoration and forgetting (Connerton 1989; Berliner 2005; Nguyen 2016; Young 1988). Winter $(2008,7)$, for example, has noted the requirement that collective, historical memories must above all be meaningful, remarking, 'Where there is no meaning, there is no commemoration'. How then are such meanings constructed, co-constructed, and shared with children and young people in the educational conversations taking place in schools, the early stages of 'finding meaning in the past' (Winter 2008, 7)?

The centenary of the First World War (2014-18) sparked a renewed interest in the remembrance of this conflict and prompted commemoration events in European and Anglophone countries marked by the Great War (Australian Government [http://www.anzaccentenary.gov.au/]; BBC 2014; New Zealand Government [https://ww100.govt.nz/]). In the United Kingdom, government funding was made available for a raft of cultural acts and events of commemoration (Jeffery 2015; Wintour 2012), including Paul Cummins's and Tom Piper's 2014 installation Blood Swept Lands and Seas of Red at the Tower of London (the Tower Poppies); Jeremy Deller's 2016 Somme centenary project We're Here Because We're Here (the Ghost Soldiers); and, in 2018, Peter Jackson's They Shall Not Grow Old and Danny Boyle's Pages of the Sea (14-18 Now 
[https://www.1418now.org.uk/]; BBC 2016; Historic Royal Palaces 2014; University of Birmingham 2018; University of Oxford 2017). Despite aims of wide public reach, however, concerns have been expressed about the top-down nature of a government-sponsored commemorative agenda, and what might have been forgotten as well as remembered. In the words of historian Sam Edwards (2013 n.p.):

$[\mathrm{T}]$ he time is now right to complicate how we commemorate $\mathrm{WW} 1 \ldots$ to reclaim the forgotten and to restore the neglected. . . to remember the [full range of] people [involved] - victors and victims, men and women, patriots and pacifists, soldiers and civilians.

In 2013 the Department of Culture, Media and Sport appointed a National Commemoration Advisory Group to provide policy direction for government-funded public events and academic research regarding the First World War centenary (Kidd and Sayner 2018). The Advisory Group's recommendations included consideration of hitherto disregarded points of view including those of women, non-British combatants and stakeholders (including those from the Commonwealth), and dissenters such as conscientious objectors. Notwithstanding these suggestions, centenary events have been criticised for promoting a simplistic and even jingoistic view of the war (Jeffery 2015), and potentially distorting historical knowledge by emphasising and reinforcing dominant narratives of the conflict - of futility and the loss and sacrifice of British (male) soldiers (Noakes 2019, Todman 2005).

In recent years First World War commemorative events, issues and cultural initiatives have attracted scholarly research, particularly in the fields of history, politics and heritage studies (for example, Jeffery 2015; Kidd and Sayner 2018; Oxford Arts Blog 2018). In terms of educational impact, studies have tended (with a few exceptions) to focus on the influence of public discourses about the First World War and its centenary on young people through the investigation of extra-curricular activities such as visits to museums, battlefields and other 
heritage sites (Kidd and Sayner 2018; Pennell 2018). Surprisingly little attention, however, has been paid to commemoration events in the school setting, in particular those marking Armistice (Remembrance) Day itself $\left(11^{\text {th }}\right.$ November). The views of school leaders and teachers of how meaning is - and should be - made with the children and young people in their care forms one strand of our study into remembrance in schools (2013-2019). In this paper we examine teachers' reported intentions and understandings of the remembrance event itself and the part they play in handing down the 'social memory' of the First World War alongside other, subsequent, conflicts.

This focus is salient given the backdrop of a society grappling with its civic and national identity in relation to a post-colonial past and multi-cultural present, and concerns over the radicalisation of young people by both Far Right and Islamist extremism. Following the attacks on the New York World Trade Center and the Pentagon on September $11^{\text {th }} 2001$, a succession of terrorist attacks on British soil, including the London transport bombings of 2005, the murders of Fusilier Lee Rigby in 2013 and of MP Jo Cox in 2016, has fuelled continuing concerns over British vulnerability to extremist atrocities. Among a range of official responses, the British government introduced a series of educational initiatives designed to build civic awareness, cohesion and responsibility. Citizenship education has formed part of the National Curriculum since 2002, with renewed guidance issued in 2013 for Key Stages 3 and 4 and in 2015 for Key Stages 1 and 2 (Department for Education 2013 and 2015). The teaching of Fundamental British Values - a key plank in the effort to connect the present to the past - has been in place since 2014 (Department for Education, 2014). The Prevent Strategy of 2015-16, initiated to counter and forestall acts of terrorism (HM Government 2015), aimed to identify potential extremist threats in children and young people in schools and Early Years settings (OCC 2015). The Birmingham Trojan Horse controversy of 2014-15 provided a stark example of moral panic (Cohen 1972) catalysed by fears of 
antithetical civic values being stealthily introduced into British schools (Arthur 2015; Awan 2018; Miah 2017). The Department of Education's 'Educate against Hate' guidance (https://educateagainsthate.com/) represents a recent example of the ongoing efforts to deploy schools and teachers in the project to bolster civil society (Department of Education 2019). This context impinges on teachers' conceptions of solidarity and collective identity that are invoked in remembrance activities in general and that have been introduced to children in schools during the centenary of the First World War.

It is worth noting that in the legal context of England and Wales, it is a requirement that 'each pupil in attendance at a community, foundation or voluntary school shall on each day take part in an act of collective worship' (Legislation.gov.uk 1998, Section 70) and that the majority of this worship, even in schools without a specifically religious character, should be 'wholly or mainly of a broadly Christian character' (ibid, Schedule 20). Therefore it is not unusual for events of remembrance to be associated with acts of Christian worship (the remembrance 'service') or for commemorations to form part of a programme of school assemblies which, while not specifying a particular denominational or religious character, encourages students to reflect on spiritual matters.

\section{Social Memory and Public Ritual}

The remembrance events considered in this research were framed by practices and enactments focused, perhaps not surprisingly, on the collective remembering of conflicts past. Such acts in themselves are orchestrated to inculcate in pupils clear, shared experiences of traditional collective behaviour intended to commemorate the human costs of participation in war. Since the 1980s considerable scholarly attention has been paid to the concept of memory and its place in human culture, through the work of scholars such as Pierre Nora, Maurice Halbwachs, Jay Winter and many others (Berliner 2005). From 2013 this scholarship has gained momentum, with public funding and attention focussed on research and 
commemorative events about the centenary of the First World War (Jeffery 2015; Kidd and Sayner 2018). Notwithstanding this, Paul Connerton's insights from the late 1980s regarding 'social memory' continue to be illuminating and are particularly relevant to an investigation into school-based commemoration events. Connerton $(1989,4-5)$ remarked that 'If there is such a thing as social memory ... we are likely to find it in commemorative ceremonies; but commemorative ceremonies prove to be commemorative only in so far as they are performative'. Connerton argues that such events are performed, habitual and embodied. His analysis of 'social habits' is pertinent to the 'habitual' aspects of traditional school commemoration observances. He writes (35): 'Social habits are essentially legitimating performances. And if habit-memory is inherently performative, then social habit-memory must be distinctively social-performative', that is, must conform to 'others' conventional expectations within the context of a system of shared meanings ... [in order to be] socially legitimate'. Similarly, Jay Winter (2010a, 12) has more recently considered the performative nature of memory, emphasising the affect involved in 'memory acts' (i.e. speech, gestures, art, or bodily enactments). Particularly significant for our purposes is his argument that the emotional components of memory acts give the initial memory, (or, for those born later, the story, passed on over time) its 'sticking power'. The 'democratisation of warfare' that began with the First World War meant that 'the history of warfare and family history came to be bound together' (Winter 2008, 6). Thus public 'social memory' and private family memories are interwoven, as, to some extent, are the emotional responses associated with each. It has been argued that public memory acts, notwithstanding their potential to join together the individual with a wider social unit, can legitimise particular readings of the past, whilst deemphasising or silencing alternative perspectives, thereby excluding those who hold these perspectives (e.g. Loewen 1995). 
Traditions of collective Armistice Commemoration - which revolve around the twominute silence, the Cenotaph in London (or local war memorials), and the symbol of the poppy - were created very soon after the end of the First World War. These traditions were devised and sanctioned by the monarch and religious and political leaders, and received considerable popular support, but during the interwar years were also seized on as opportunities for demonstrations, sometimes violent ones, and the voicing of dissenting views Gregory 1994, MacLeod and Inall 2019).

Perhaps the most prominent memory act involved in the public commemoration of the First World War is the collective observation of a two-minute silence, a tradition entrenched in social memory through radio and television broadcasts as well as public ceremonies since the 1920s. This public silence originated in South Africa during the War but was adopted in 1919 to coincide with the timing of the cessation of hostilities - on the Western Front - at 11 am on November $11^{\text {th }} 1918$ (Brown 2012; Gregory 1994; Macleod and Inall 2019). Scholars, including Paul Young (1988), emphasise the appropriacy of muteness as a commemorative response to the tragedy and loss involved in armed conflict and atrocities such as the Holocaust; Vinitzky-Seroussi and Teeger $(2010,1117)$ describe such public silences as 'perhaps the highest official honor that can be granted to the past'. Winter (2010b, 4) characterises these silences as 'liturgical', since 'public understandings of war and violence ... touch on the sacred, and on eternal themes of mourning, sacrifice and redemption'.

Steven Brown $(2012,242)$ interprets silence - the "powerful evocation of the failure of words to gain purchase on the enormity of sacrifice' - as an example of a 'social technology', which he defines as 'that which enables as its primary object the selfmodification of some subjective state of affairs of a human subject' (238). Brown argues that one result of the silence and the physical stillness that accompanies it - representing a 
temporary, collective rupture in routine - is to transform those who observe it briefly into living 'temporary monument[s]' (248). Commemorative silence in schools has received little scholarly consideration. One small-scale study, however, has considered student perceptions of the regular observance of silence in a Quaker school (Wood and Tribe 2016). The authors found that, among their secondary-school-age participants 'silence appears to be a deeply relational experience' (145) that fostered both a range of individual subjectivities and a sense of community. Students valued the individual reflection time and sense of self-determination afforded by the period of silence, and found that over time it led to 'a sense of connectedness' (149).

\section{Remembrance in Schools}

The literature to date on remembrance in schools is relatively scant, and over the centenary period has tended to focus particularly on the First World War. The school-based studies that exist all focus on secondary school students, and generally centre on the transmission of beliefs, values and cultural narratives through specific classroom subjects such as history (Pennell 2016), literature (Chinnery 2014) or social studies (Sheehan and Davison 2017). Several of these focus on non-British contexts such as New Zealand (Sheehan and Davison 2017) and Canada (Chinnery 2014). Other related studies focus on out-of-classroom provision such as museum offerings, heritage events and visits to battlefields (Kidd and Sayner 2018; Pennell 2018).

A number of studies are informed by theorisation located primarily in the philosophy of education, related to issues of historical consciousness and the importance of remembrance in moral education (Chinnery 2010; Gordon 2015; Sheehan and Davison 2017). They emphasise what Chinnery describes as ‘the moral significance of memory' (Chinnery 2014, 587), and the affective as well as cognitive avenues to a deeper understanding of both the universal human dilemmas and specific historical experiences represented by the First World 
War. Chinnery distinguishes between a cognitive approach emphasising accurate knowledge and understanding, and a critical approach that demands learner engagement with questions of the ethical responsibilities that the past entails upon the present.

Similarly advocating a critical approach, and directly confronting normative questions regarding what schools ought to do in commemorating armed conflicts, Aldridge argues that the only defensible justification for the remembrance of war dead in schools is to remind children about the horrors of war. He rejects justifications of remembrance activities based either on the grounds of eliciting children's gratitude for the sacrifices of war, or of inculcating shared social values. For these justifications, he contends, the desired sentiments are not known without reasonable contestation to be appropriate. Furthermore, they stifle students' freedom to 'question the legitimacy of the great conflicts of history without being encouraged to feel that doing so somehow undermines a shared set of values for which so many have given their lives' (Aldridge 2014, 32). Aldridge also suggests that schools should avoid selling poppies on school premises (while not prohibiting students from wearing them) and suggests, '[I]f we want children to think on the horror of war, perhaps we should be substituting images of children whose lives have been cut short...in conflicts... [rather than] bright red flowers, pristine stone memorials, and elderly men wearing medals' (38).

Although evaluation of centenary events is necessarily in its early stages, scholarly research to date has suggested that the guidance on including hitherto unrepresented points of view has not been explicitly reflected in responses by teachers, schools and young people as to the meanings of commemoration and the teaching of the history of the First World War (Kidd and Sayner 2018; Pennell 2016). Kidd and Sayner, for example, note the tenacity of what they view as received opinions in the responses of museum visitors regarding the meaning and significance of the First World War, remarking that 'ritualised memory discourses are difficult to disrupt' $(2018,12)$. 


\section{Methodology}

The empirical research discussed in this paper employed two successive online surveys followed by interviews with a sample of school leaders, teachers, or other relevant staff in primary and secondary schools. In the autumn term of 2013 an email request was sent to the school leaders of all 1,034 primary, secondary, preparatory and special schools in a threecounty area in southern England. The request invited participants to complete a short online survey of 10 questions via an attached web link, providing, through closed questions, quantitative data on the nature of the school's remembrance activities, and, through free-text questions, qualitative data of educators' understandings of what these activities meant. The 2013 survey received a $12 \%$ response rate, with 121 schools responding, of which $65 \%$ were primary schools $(n=79)$ and $35 \%$ secondary schools $(n=42)$. The same survey invitation was sent in the autumn term of 2016 to all primary, secondary, preparatory and special schools in the same three-county area (which by then numbered 1,098). The response rate in 2016 was again $12 \%(\mathrm{n}=132)$, with an increase in the proportion of responses from primary schools $(77 \%: n=102)$ compared to secondary schools $(23 \%: n=30)$.

In both iterations the surveys were completed by a self-selected sample of participants: school leaders and other staff who were sufficiently interested in the study to respond. The invitation email requested that headteachers who preferred not to answer the survey themselves might pass it along, at their discretion, to relevant staff. Perhaps unsurprisingly, primary headteachers were more likely to respond to the survey themselves. Secondary heads from responding schools often passed the survey to others in the school: teachers or mid-level leaders with relevant curricular responsibilities, school chaplains, or administrative and marketing staff.

The survey invited respondents to volunteer for more in-depth interviews. From the pool of self-nominated participants, interviews were conducted with 12 primary school and 
five secondary school teachers in the Spring of 2017, with one further primary teacher interview held in Spring 2018. Not all interviewees were classroom teachers, but all had teaching responsibilities as part of their role. Interview questions centred on the activities schools engaged in on Remembrance Day, what teachers believed was being remembered, and what they thought these things meant. The interviews were audio recorded, and notes taken of key points; interviewer notes were validated, and emerging themes discussed, by project team members working together.

Both the survey and interview data represented self-reported information and views from a self-selected sample. The sample size for teacher interviews was small and confined to a specific region in southern England. Findings cannot therefore be regarded as representative. Instead, they are indicative of the attitudes and values of a thoughtful sample of educators with something to say on the issue of remembrance in schools, rather than those with less interest in remembrance, or, potentially, those with significant misgivings about the enterprise. The insights they provide, however, may prove thought-provoking and helpful as a source of ideas and developing practice for other schools and educators, as well as contribute to the theorisation of remembrance activities in schools.

\section{Findings}

\section{Surveys}

The most common school remembrance activities reported were very similar in the two surveys. Primary and secondary schools were not substantially different in their responses, with both phases overwhelmingly reporting events that included periods of silence $(90 \%$ in $2013,92 \%$ in 2016) and special Remembrance Day assemblies or events ( $80 \%$ in $2013,82 \%$ in 2016). Smaller percentages noted main Remembrance Day events taking place in lessons (43\% in $2013,38 \%$ in 2016$)$ or integrated into normal assemblies $(15 \%$ in $2013,12 \%$ in 2016), a few reported visits to local churches or other memorial sites. The use of poppies was 
prevalent in free-text comments in both surveys on activities and events, with reports of poppy selling at school, laying of poppy wreaths on memorials (at the school or another site), and laying of poppies on graves. The most commonly used words and concepts in free-text responses to the question 'What was being remembered?' were as follows:

- 2013: (1) Died; (2) Lives ('gave lives/lost lives’); (3) School; (4) World Wars; (5) Soldiers.

- 2016: (1) Conflict; (2) Poppy; (3) Died; (4) Lost their lives; (5) World War One. Unsurprisingly, responses invoked themes of death and loss connected with armed conflict. The increased emphasis on the First World War and poppies in 2016 might, arguably, reflect wider discourses and acts of commemoration during the centenary period, but generally the concepts used in both surveys were remarkably similar.

\section{Interviews}

Themes emerging from the interviews included aspects of the expected and traditional. These were elaborated, however, by thoughtful and contemporary interpretations of a range of meanings associated with the Remembrance Day observances and the act of remembrance itself. Among the expected themes in teachers' responses were those that mirror public observances and traditions, such as the ubiquity of the poppy as a symbol and the observance of silence, wreath-laying, the playing of the Last Post and the reading (in the case of secondary schools) of rolls of honour. Variations on the poppy theme in primary schools included children (in a school with red jumpers as part of the uniform) forming into a 'human poppy' during the school event, and the 'planting' of pupil-constructed poppies around flagpoles and in small 'gardens of remembrance'. One secondary school teacher created an 'alternative' war memorial constructed of barbed wire around a dead tree, a response to student comments after a battlefields tour. 
The interviews revealed that public discourses surrounding the centenary of the First World War had an impact on some remembrance events in schools. Interviewees reported attempting larger events than previously, with a greater focus on inviting community members to the school event, or integrating school events with those of the wider community; 'It's nice for the community to see that we do it', said a teacher at a village primary school. Where observances in schools did not change, teachers reported enhanced engagement of staff and pupils in events because of greater awareness as a result of the centenary. In one secondary school, for example, the interviewee saw the centenary as an occasion for 'reemphasising', but not for fundamentally changing, patterns of observance maintained for at least 30 years and 'inherited' from predecessors. Teachers were alert to the availability of a range of nationally- and locally-focussed learning resources on Remembrance and the First World War as a result of the centenary. They also drew inspiration from public cultural acts and events; some teachers reported, for example, that their school's poppy artwork was inspired by the Tower Poppies.

Teachers were concerned to connect wider national and international events to the local and the personal. This could involve inviting visitors such as veterans from the local community or assigning students to research individual local soldiers. Learners, especially in primary schools, were often encouraged to bring family memorabilia (objects, letters, and newspaper clippings) into school. The emphasis on family history was equally present when the school community was diverse and encompassed different nationalities, ethnicities and religions. Different family experiences of the same conflicts were understood as being part of a shared past and identity. For some teachers, incorporating different family experiences and beliefs was valued as an opportunity for telling different stories, but this required careful thought and sensitivity; as one teacher noted, 'We need to avoid the notion that we are religiously-biased or that we are all the same'. Difficult questions could arise, a secondary 
school teacher commented, when remembrance activities included students whose ancestors were on the 'losing' side. In secondary schools founded before 1914, teachers reported emphasising the continuity between contemporary students and those attending the school during the First World War, who might have been called upon to fight and die during the conflict. This was underscored by the reading of rolls of honour or names on school memorials. As one teacher put it: 'Because these were boys that had been in the school ... I think [current students] could appreciate exactly what had happened and what it meant'.

The teachers interviewed felt they had a responsibility to discuss the difficult moral and existential questions raised by Remembrance Day events. There was a strong focus on recognising the lives lost and injuries sustained among serving personnel in wartime, particularly in the world wars but also in other conflicts. There was also, though to a lesser extent, attention to the impact of war on whole families and communities, its 'knock-on effects', as one teacher put it. Teachers in both primary and secondary phases emphasised the crucial aspect of learning from the past to contribute to a better future, making children aware of the consequences of war in order to ensure that previous sacrifices were not in vain. This might involve consideration of how to avoid future conflict through peaceable interactions, reflecting, as one interviewee put it, on 'how, as a people, we can actually live together well'. For another interviewee, pupils had to be made alert to the situations in which conflicts might arise, to 'see the signs', to 'learn from the past and be aware'. These teachers felt that pupils needed to be encouraged to take responsibility themselves, to regard themselves as 'young custodians of the future'. The focus was on remembering, so that tragedies may not be repeated.

Difficult existential questions also included the fundamental facts of loss and death. Particularly in primary schools, teachers noted that Remembrance Day activities precipitated discussion of these issues, and reported endeavouring to create a 'safe' opportunity for 
children to consider them in a balanced, 'quiet and calm', age-appropriate way. Teachers sought to facilitate addressing 'darker stuff' whilst avoiding scaring children or 'romanticising death'. For secondary school teachers, remembrance activities were an opportunity to raise questions and get pupils to think through controversial issues. One wanted to enable pupils to ask 'What should we be talking about here ... What is this about?'; another aimed not to teach 'any specific perspective on what remembrance should be' but to 'present the themes and help them to draw the conclusions themselves'.

In some schools, a heightened awareness of the ongoing impact of war, and sensitivities arising from this, arose from proximity to a military base, or because the school demographic included parents who had served in the military. The needs of service families among pupils and staff were recognised, and interviewees were alert to the heightened significance of current conflicts, and the potential sensitivities of those attending the school's remembrance events. Current and recent conflicts were also significant in an urban primary school with pupils whose families had recently come to Britain from war zones. The headteacher felt it was appropriate, during the school's commemoration activities, to make reference to refugee and migration status, and to ongoing conflicts, in an age-appropriate and sensitive manner.

A notable finding from the interviews was the importance teachers placed on pupils' observation of the two-minute silence, the significance of this silence and its attendant physical stillness, and their satisfaction when pupils - even those as young as four years old were able to enact it. 'They kind of gleaned exactly how they should be in that situation'; 'You could have heard a pin drop'. Teachers believed this was more than simply an issue of conformity to accepted standards of good behaviour in a specific traditional context (although there were aspects of this). Rather, it served as what we might term the outward and visible sign of an appropriate attitude or response of reverence in the face of fundamental issues of 
life and death, and the consequences of choices (or lack of choices) in the context of war. Moreover, silence and the opportunity to be still were also thought to have benefits for students beyond the immediate circumstance of war commemoration. Teachers emphasised the value for children of 'stillness', and being 'mindful', and learning habits of quiet thought. These were deemed, as one teacher put it, 'skills and behaviours which will be applicable in other situations'. For this behaviour to have impact and meaning, they suggested, it had to be modelled by adults too; interviewees stressed the importance of the silence being observed by all adults in the school - catering, support and facilities staff as well as teachers.

\section{Discussion}

The November 2013 survey at the start of the centenary of the First World War, and the subsequent 2016 survey at around its midpoint, both returned results that were in many respects 'conventional' and predictable. Schools reported selling (and otherwise engaging with) poppies as well as staging commemorative rituals similar to those that take place annually in the wider public domain. The open-ended questions in the survey, however, and especially the interviews with teachers, revealed that educators' beliefs and understandings about what these remembrance activities mean were more nuanced, intentional and proactive (at least in the sample schools) than the prima facie adherence to 'tradition' evident in their responses might indicate at first glance.

Remembrance activities in schools self-consciously connect past and present by involving children and young people in both cognitive and affective learning. The continuity involved in the traditional observations may be regarded as being the point, in the sense that the tragic (and sometimes heroic) aspects of the human condition acknowledged in the wellworn ceremonies are universals that transcend time, and therefore connect the present to the past, as ‘social memory' (Connerton 1989, 1) or 'historical remembrance' (Winter 2008, 6). Questions raised in the wider public sphere about which groups were included or excluded in 
commemorations during the First World War centenary period were raised explicitly by only a few participants. Yet the need to engage with such questions was implied in teachers' references to the thought required in getting the right 'balance' and mode of expression, and to encountering and addressing uncomfortable questions when pupils' ancestors fought on different sides in the world wars.

Unthinking cultural conservatism, for our interviewees, was not the point of Remembrance Day traditions, which were, instead, considered to be a source of connectedness within a school community, as well as an opportunity to connect to a wider community that integrates past and present. Continuity and repetition, moreover, had a specifically educational value. It enabled pupils to learn from the occasion over time, offering security when addressing difficult questions and helping them to access and make meaning by building their understanding iteratively year on year.

At the same time, the well-worn ceremonies were often contextualised, updated and refreshed in schools' Remembrance Day rituals themselves, in wrap-around classroom learning and discussion, or in both. In a few cases, this contextualisation explicitly referenced and emphasised the viewpoints of hitherto-neglected voices such as those of women, commonwealth citizens, and conscientious objectors, as recommended by the National Commemoration Advisory Group, and extended this emphasis to contexts beyond the First World War. For example, for one primary school teacher there was overt emphasis on service families, but this included a recognition of the varieties of cultural and social heritage involved; 'It's so important as part of their historical and cultural background, and the diversity of soldiers is also a big part of what we do'. In more cases, such themes were subtly integrated with traditional themes and rituals, in ways intended to be intelligible to children and young people. The emphasis on family histories substantiates Jay Winter's (2008) point that the history of mass warfare articulates intimately with family history, and has been noted 
by Lucy Noakes (2019) as a motivation for involvement in commemorative projects and events during the First World War centenary period. Focusing on family in relation to the First World War has been problematised as potentially leading to an ethnocentric European focus and incomplete knowledge about the complexities and global nature of the conflict (e.g. Pennell 2016, 2018). Our interviewees however were less concerned that school remembrance activities generated nuanced and accurate historical knowledge than that they made history meaningful, brought it to life, and encouraged contemplation of the questions it poses about the human condition. This chimes with Brown's $(2012,239)$ proposition that: the question of whether commemorative silence enables "better" remembering that is, more faithful or realistic recollections - is not the most pressing. What is instead at issue is what modes of access to the past are opened up through public silence and the forms of experience that are thereby afforded.

For one secondary school teacher, remembrance events were not for teaching students new facts about war, but for 'reminding them of what they know'. Depending on the demographics of the school, family histories could incorporate different sides of the First World War (and indeed subsequent conflicts) and represent the points of view of different ethnic and religious groups, not only to the pupils involved, but also to their fellows.

In some schools, also, contextualisation and adaptation related not only to government-sponsored commemorative agendas but also to other approaches to organising teaching and learning. In some primary schools a value-based curriculum (with a new value each month on a rolling basis) meant different 'values of the month' could be connected with remembrance: teachers appreciated the opportunity this afforded to 'say something new' and integrate fresh messages within the framework of the traditional, habituated observances. In this way, the familiar remembrance rituals could be revisited and give rise to deeper and more 
nuanced ethical and existential insights, what Brown $(2012,238)$ terms 'the means by which the newly thinkable subject might be conceived in some other manner'.

The specific and widely prevalent emphasis on silence and stillness - and educators' pride that their students achieved this - may be interpreted not merely as the inculcation of conventional, conformist behaviour in the face of unquestioned public pieties. An unusual choice of action, such as - in the case of the two-minute silence - the lack of utterance or movement, marks an out-of-the-ordinary moment, a pause, a moratorium on normal behaviour. This commemorative response betokens reverence, thoughtfulness, and a willingness to engage imaginatively and existentially - and to demonstrate, and indeed embody, this willingness. The reverent behaviour that teachers expected and facilitated at collective remembrance ceremonies (even among primary age pupils for whom such behaviour might have been deemed difficult to achieve) contributed to their sense of a highlycharged occasion, and resonates with Connerton's and Winter's notions of the performative, enacted, and emotional aspects of social memory and with Winter's formulation of 'liturgical silence' (Connerton 1989; Winter 2008; Winter 2010b, 4). Brown $(2012,242)$ has noted the educative aspect of public commemorative silence, observing that 'the bracketing of the silence into two minutes turns this experience into [a] simple pedagogical exercise, where the speech which follows the silence appears endowed with a far greater rhetorical and emotional power than might otherwise have been suspected'. Teachers appeared to appreciate this sense of the interplay between ritual silence and the educative speech that preceded and followed it, recognising the importance of the silence both in enabling receptivity and in constituting a meaningful experience in itself for the children and young people in their care.

Teachers saw in the silence not only an appropriate act of commemoration. They also perceived a valuable opportunity to teach children to be still and mindful; this, they suggested, would be of benefit to them within the school more generally, and in settings 
beyond. The unusual act of being still and calm was allied to educational discourses, such as mindfulness, prevalent in the wider public sphere and valued for this reason, giving the silence meaning for teachers beyond its place within the specific act of armistice commemoration.

The teachers we spoke to saw the First World War centenary, and the social rituals mounted to mark it, as an opportunity to look back in time into individual, family, national and transnational tragedy. Handling the traditional, embodied rituals surrounding this particular social memory demanded sensitivity, moral courage, engagement and creativity on the part of teachers, who were mindful of their responsibilities to contextualise and interpret larger public observances in ways that children and young people could make sense of. It may be that the century that has elapsed between the First World War and the present allowed teachers a degree of 'safety' in confronting the moral and political controversies raised by that war (and subsequent but still distant wars such as the Second World War). Teachers regarded this as an opportunity (and for several participants, as a moral imperative) to explore with children some of the big questions about armed conflict and the tragic consequences that follow even when a war may be judged to have some justification.

Teachers were aware that commemoration events inevitably raised existential and spiritual questions about the nature of loss, duty, courage, sacrifice, and the consequences of injury and bereavement. These questions tended to emerge and be discussed in different ways for different ages of children. For teachers in primary schools, a key aim was guiding children to an understanding of the fact that the First World War - and subsequent conflicts happened, and implicated families like their own. Educators in some of the secondary schools felt able to introduce themes that resonated more with the 'critical' stance of Aldridge, Chinnery and Pennell (Aldridge 2014, Chinnery 2014, Pennell 2016), challenging learners to consider concepts and issues that demanded greater levels of intellectual, moral, 
psychosocial, and political sophistication. Teachers in both phases encouraged students to 'consider how we might avoid repeating events in the past', as one put it. The type of understanding teachers believed themselves to be facilitating was not simply cognitive, but also affective and existential.

\section{Conclusion}

In this under-researched area, teachers' reports of their schools' commemorative events on Remembrance Day, and their views of the meanings of these, indicate a complex set of values and understandings underlying a surface appearance of adherence to tradition and received ideas. Those we spoke to typically aimed for sensitivity and balance, inclusive of pupils and staff of different ethnic, national and religious backgrounds, striving, as one teacher put it, to be 'not jingoistic' but rather 'allowing for differing points of view on history and on the military'. They aimed to honour the specific experiences and cater for the specific needs of the students and staff in their school communities. The conversation between generations that Peters (1966) spoke of involved, for these teachers, the facilitation of affective as well as cognitive learning and development, and entailed the enacted and performed as well as the explicitly taught.

In our research with schools we found that an emphasis on 'tradition' and traditional (i.e. habituated), performed rituals was important to teachers in communicating a sense of the collective social import of the First World War and other armed conflicts. Each of Connerton's (1989) three aspects of 'social habits', the performative, the habitual, and the embodied, has resonance for our findings. Our research uncovered an emphasis on ceremony and ritual in schools (the performed aspect), the value teachers placed on the repetition of traditional observances (the habitual aspect), and the importance to teachers of learners' behaviours (embodied aspects), demonstrated by teachers' pride in children's ability to stand 
still and maintain silence as an appropriate, enacted response to the meaning inscribed in the Remembrance ceremony in its varieties and similarities.

Recent research trends and public policy emphases in response to the centenary of the First World War seemed not, for many of our participants, to have disrupted the traditions and traditional meanings ascribed to remembrance events in their schools. Where calls were heeded to recognise and represent the views of previously invisible participants of the war, schools included these as additions rather than replacements of the traditional observations. These frequently took the form of acknowledgements of the family histories of members of the school or its surrounding community, and this was in keeping with wider trends in commemoration during the centenary period (Noakes 2019). Generally, the educators who took part in our project endeavoured, in a balanced and grounded manner, to communicate, connect and integrate past and present in child-friendly ways, relevant to their schools and local communities.

From the testimony of the teachers participating in this study, we may conclude that school Remembrance Day events partake of the character of commemoration rituals in the wider society (as well as being contextualised in a range of ways to take account of the school community and the age of learners). For this reason, we may also infer that the nuanced psychosocial character of public commemoration rituals also pertains in school events. Specifically, the character of social memory as performed, habitual and embodied, and the complex subjectivities elicited by the social technology of the two minutes silence, are present in age-appropriate ways in schools. Teachers were at pains to induct the children and young people in their care into these rituals of social memory as members of a wider society remembering the First World War (and indeed subsequent conflicts), to enable the making, and remaking, of meaning with regard to these complex and troubling historical events. 


\section{References}

Aldridge, David. 2014. How Ought War to be Remembered in Schools? Impact No. 21.

Wiley/Philosophy of Education Society of Great Britain.

https://onlinelibrary.wiley.com/doi/full/10.1111/2048-416X.2014.12001.x.

Arthur, James. 2015. "Extremism and Neoliberal Education Policy: A Contextual Critique of the Trojan Horse Affair in Birmingham Schools." British Journal of Educational Studies 63 (3): $311-328$.

Awan, Imran. 2018. “'I Never Did Anything Wrong” - Trojan Horse: A Qualitative Study Uncovering the Impact in Birmingham.” British Journal of Sociology of Education 39 (2): $197-211$.

BBC. 2014. "In Pictures: World War One Anniversary." BBC News, August 5. Accessed 25 June 2018. https://www.bbc.co.uk/news/uk-28636232.

BBC. 2016. “Artists Behind 'Ghost Soldiers' Project Revealed.” BBC News, July 1. Accessed 24 February 2018. http://www.bbc.co.uk/news/entertainment-arts-36682140.

Berliner, David. 2005. "The Abuses of Memory: Reflections on the Memory Boom in Anthropology." Anthropological Quarterly 78 (1): 197-211.

Brown, Steven D. 2012. "Two Minutes of Silence: Social Technologies of Public Commemoration." Theory and Psychology 22 (2): 234-252.

Chinnery, Ann. 2010. "What Good Does All This remembering Do Anyway? On Historical Consciousness and the Responsibility of Memory." Philosophy of Education Archive 2010.

Champaign, Ill: Philosophy of Education Society.

Chinnery, Ann. 2014. “On Timothy Findley's The Wars and Classrooms as Communities of Remembrance." Studies in the Philosophy of Education 33: 587-595.

Cohen, Stanley. 1972. Folk Devils and Moral Panics. London: MacGibbon and Kee.

Connerton, Paul, 1989. How Societies Remember. Cambridge: Cambridge University Press. 
Department for Education. 2013. National Curriculum in England: Citizenship Programmes of Study. Accessed 4 March 2019. https://www.gov.uk/government/publications/nationalcurriculum-in-england-citizenship-programmes-of-study.

Department for Education. 2014. Promoting Fundamental British Values as Part of SMSC in Schools. Accessed 5 June 2019. https://www.gov.uk/government/publications/promotingfundamental-british-values-through-smsc.

Department for Education. 2015. Citizenship Programmes of Study: Key Stages 1 and 2. Accessed 4 March 2019. https://www.gov.uk/government/publications/citizenshipprogrammes-of-study-for-key-stages-1-and-2.

Department for Education. 2019. Educate against hate. Accessed 5 June 2019. https.//educateagainsthate.com/.

Edwards, Sam. 2013. "Viewpoint: How Should We Remember a War?” BBC News Magazine. 5 November. Accessed 9 May 2019. http://www.bbc.co.uk/news/magazine24610481.

Gordon, Mordechai. 2015. "Between Remembering and Forgetting." Studies in the Philosophy of Education 34: 489-503.Gregory, Adrian. 1994. The Silence of Memory: Armistice Day 1919-1946. Oxford: Berg.

Historic Royal Palaces. 2014. Tower of London Remembers. Accessed 26 April 2018. http://www.hrp.org.uk/tower-of-london/history-and-stories/tower-of-londonremembers/about-the-installation.

HM Government. 2015. Revised Prevent Duty Guidance for Specified Authorities in England and Wales on the Duty in the Counter-Terrorism and Security Act 2015 to Have Due Regard to the Need to Prevent People from Being Drawn into Terrorism. London: Crown Copyright. Ingold, Tim. 2017. Anthropology As/Of Education. London: Routledge. 
Jeffery, Keith. 2015. "Commemoration in the United Kingdom: A Multitude of Memories." Australian Journal of Political Science 50 (3): 562-567.

Kidd, Jenny and Joanne Sayner. 2018. "Unthinking Remembrance? Blood Swept Lands and Seas of Red and the Significance of Centenaries." Cultural Trends 27 (2): 68-

82.Legislation.gov.uk. 1998. School Standards and Framework Act Schedule 20.

http://www.legislation.gov.uk/ukpga/1998/31/schedule/20

Accessed 10 October 2019.

Loewen, James W. 1995. Lies My Teacher Told Me: Everything Your US History Book Got Wrong. New York: The New Press.

Macleod, Jenny and Inall, Yvonne. 2019. “A century of Armistice Day: memorialisation in the wake of the first world war." Mortality. Advance online

publication. https://doi.org/10.1080/13576275.2019.1611752.

Miah, Shamim. 2017. "The Muslim Problematic: Muslims, State Schools and Security.” International Studies in Sociology of Education 26 (2): 138-150.

Noakes, Lucy. 2019. “Centenary (United Kingdom)". In: 1914-1918 online. International Encyclopedia of the First World War, edited by Ute Daniel, Peter Gatrell, Oliver Janz, Heather Jones, Jennifer Keene, Alan Kramer, and Bill Nasson, issued by Freie Universität Berlin, Berlin 2019-06-03. DOI: 10.15463/ie1418.11369.

Nguyen, Viet Thanh. 2016. Nothing Ever Dies: Vietnam and the Memory of War. Cambridge, MA and London: Harvard University Press.

Oxford Arts Blog. 2018. “How do we Remember War?” June 15. Accessed 22 June 2018.http://www.ox.ac.uk/news/arts-blog/how-do-we-remember-war.

Oxfordshire County Council. 2015. British Values and the Prevent Duty. September. Accessed 6 June 2019. http://www.oscb.org.uk/wpcontent/uploads/British_values_and_the_prevent_duty.pdf. 
Pennell, Catriona. 2016. "Learning Lessons from War? Inclusions and Exclusions in Teaching First World War History in English Secondary Schools.” History and Memory 28 (1): 36-70.

Pennell, Catriona. 2018. "Taught to Remember? British Youth and First World War Centenary Battlefield Tours." Cultural Trends 27 (2): 83-98.

Peters, R. S. 1966. Ethics and Education. London: Allen and Unwin.

Sheehan, Mark and Martyn Davison. 2017. “'We Need to Remember They Died For Us': How Young People in New Zealand Make Meaning of War Remembrance and Commemoration of the First World War." London Review of Education 15 (2): 259-270. Todman, Dan. 2005. The Great War: Myth and Memory, London: Hambledon/Continuum. University of Birmingham. 2018. "Voices of War and Peace.” Accessed 25 June 2018. https://www.birmingham.ac.uk/research/activity/education/projects/voices-of-war-andpeace.aspx.

University of Oxford. 2017. “Oxford University Leads National Effort to Save WW1 Memories.” Accessed 25 June 2018. https://innovation.ox.ac.uk/news/lest-we-forget/. Vinitzky-Seroussi, Vared, and Chana Teeger. 2010. "Unpacking the Unspoken: Silence in Collective Memory and Forgetting." Social Forces 88 (3): 1103-1122.

Winter, Jay. 2008. "Historical Remembrance in the Twenty-First Century." Annals of the American Academy of Political and Social Science 617: 6-13.

Winter, Jay. 2010a. "Introduction. The Performance of the Past: Memory, History, Identity." In Performing the Past: Memory, History and Identity in Modern Europe, edited by Karin Tilmans, Frank van Vree and Jay Winter, 12-35. Amsterdam: Amsterdam University Press. Winter, Jay. 2010b. “Thinking about Silence.” In Shadows of War, edited by Efrat Ben-Zeev, Ruth Ginio, and Jay Winter, 3-31. Cambridge: Cambridge University Press.

Wintour, Patrick. 2012. "David Cameron Announces £50m Fund for First World War 
Commemorations." The Guardian, October 11. Accessed 19 April 2016.

http://www.theguardian.com/politics/2012/oct/11/david-cameron-fund-world-war-onecommemorations.

Wood, Margaret and Robert Tribe. 2016. "In a Silent Way: Student Perceptions of Silence in Community." Pastoral Care in Education 34 (3): 144-155.

Young, James E. 1988. Writing and Rewriting the Holocaust: Narrative and the Consequences of Interpretation. Bloomington: University of Indiana Press. 